\title{
Konseling Keluarga Sebagai Model Konseling pada Anak dengan Kecanduan Masturbasi
}

\author{
Selvy Putri Fabiola ${ }^{1}$ \\ ${ }^{1}$ Fakultas Teologi, Universitas Kristen Satya Wacana, Salatiga, Indonesia \\ dakamolyselvy@gmail.com
}

Received March 17,2021; Revised Month DD, 20YY; Accepted September 14, 2021 Published Online September 14, 2021

\section{Conflict of Interest Disclosures:}

The authors declare that they have no significant competing financial, professional or personal interests that might have influenced the performance or presentation of the work described in this manuscript.
Abstract: This study aims to offer family counseling as a model of counseling for children with masturbation addiction. The busyness of parents in daily activities and work results in a lack offree time with their children so that parents fail to carry out their functions. One of the failed functions is to provide sex education to children so that media pollution causes children to fall into sexuality problems, one of which is the addiction to masturbation. Guidance and counseling have a significant role and influence in the non-formal realm, in the context of preventing, developing and improving the life and roots of the personal and social problems of children in the family. Techniques Refarming or relabeling in family counseling used by the author to provide new information to parents, information that is able to answer the needs of family members. The method used in this research is qualitative. The data collection technique is to conduct in-depth interviews to gather various important information from clients.

Keywords: Counseling, Family Counseling, Masturbation.

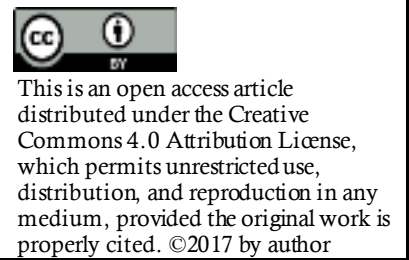

properly cited. (C2017 by author

How to Cite: Selvy Putri Fabiola ${ }^{1}$ 2021. Konseling Keluarga Sebagai Model Konseling pada Anak dengan Kecanduan Masturbasi. JJBK Undiksha, V.12 (02): pp. 167 - 175 , DOI: 10.23887/jibk.v12i2.33143

\section{Pendahuluan}

Masturbasi adalah stimulasi organ genital (seks), biasanya dengan tangan, tanpa melakukan hubungan intim. Bagi laki-laki masturbasi adalah merangsang penis dengan mengusap atau menggosok-gosoknya. Sedangkan bagi perempuan, masturbasi biasanya termasuk mengusap-usap dan menggesek-gesek daerah kemaluan terutama klitoris dan vagina. Masturbasi digolongkan ke dalam kegiatan memuaskan diri sendiri. Tetapi kadang dapat pula terjadi pada satu pasangan yang merangsang alat kelamin lawan jenisnya untuk mencapai orgasme. Masturbasi juga biasanya dinamakan "bermain dengan diri sendiri". 1

\footnotetext{
${ }^{1}$ Robert P.Masland, It's All About S Sex : A-Z tentang Sex, (Jakarta:Bumi Aksara,2013),43, 115-116
} 
Masturbasi dimulai ketika anak memasuki masa pubertas.Pubertas merupakan masa perkembangan fisik yang cepat ketika reproduksi seksual pertama kali terjadi. ${ }^{2}$ Di masa pubertas manusia mampu untuk mencatat dan mengumpulkan kebenaran-kebenaran yang fundamentil. Dalam masa ini juga, dapat diletakan dasar yang kuat untuk pembentukan watak. Tetapi pembentukan watak tersebut bukan soal pengetahuan namun soal hidup dan pengahyatan. ${ }^{3}$ Pada saat pubertas, perasaan-perasaan seksual anak akan mulai aktif dan di saat inilah terdapat kecenderungan untuk melakukan aktifitas seksual. Masturbasi merupakan salah satu aktifitas sekual yang dilakukan anak ketika dalam masa pubertas.

Masturbasi adalah bagian yang normal dalam penemuan diri. Meskipun tidak esensial terhadap proses fisik dari perkembangan seksual manusia, masturbasi merupakan kegiatan yang umum dilakukan baik lakilaki ataupun perempuan. Masturbasi mungkin memiliki nilai psikologis yang positif sebagai cara untuk membebaskan ketegangan seksual dan melepaskan energi seksual. Tidak ada efek samping secara jasmaniah akibat melakukan masturbasi. Kalaupun ada istilah efek samping mengindikasikan moralitas, sikap yang mengupas secara kritis bahwa masturbasi merupakan ketidaknormalan. Bukan masalah yang luar biasa selama masa remaja, bagi laki-laki maupun perempuan, jika mereka merasa bersalah atau malu melakukan masturbasi. Rasa bersalah ini biasanya berasal dari para remaja yang mempercayai bahwa orang tua mereka atau orang dewasa lain akan mencela kegiatan itu atau karena stigma sosial dikaitkan terhadap masturbasi. ${ }^{4}$ Namun perlu disadari bahwa masturbasi yang berlebihan dapat berdampak pada perilaku seksual anak dan membuatnya dapat jatuh ke dalam persoalan seksualitas.

Persoalan seksualitas merupakan salah satu fakta yang tak terhindarkan dalam kehidupan masyarakat yang diwarnai dengan berbagai macam fenomena yeng melibatkan generasi muda. Salah satu penyebabnya adalah disfungsi keluarga. Disfungsi keluarga disebabkan oleh pendidikan moral yang kurang memadai, etika pendidikan keluarga yang melemah, polusi media dan tekanan teman sebaya dan orang dewasa. Hal-hal tersebut berkontribusi terhadap degenerasi moral masyarakat, termasuk pelecehan dan kekerasan seksual, kehamilan, aborsi, dan perilaku tidak bertanggung jawab. Perilaku yang gagal mengikuti norma-norma sosial dalam masyarakat ini, berdampak buruk pada komponen perilaku, yaitu kualitas moral yang melekat pada nilai-nilai individu. Hal tersebut menyebabkan stres, depresi, perilaku negatif, menyalahkan diri, merasa diri kotor, dan ternoda, kebencian terhadap laki-laki atau perempuan, merasa tidak layak dan tidak pantas dikasihi dan dicintai. ${ }^{5}$

Salah satu penyebab disfungsi keluarga adalah kurangnya waktu luang (qulity time) yang dihabiskan bersama anggota keluarga. Quality time adalah waktu yang digunakan secara efektif oleh semua anggota keluarga untuk meningkatkan kualitas hubungan. Waktu untuk berbicara, berkumpul, berdiskusi, dan bercengkerama bersama di tengah kesibukan, menciptakan kualitas hubungan tetap harmonis, menjadi tujuan dari sasaran pencapaian dari keluarga yang berkomitmen, konsekuen dan konsisten menyadarkan semua anggota keluarga bahwa qualitty time adalah suatu kebutuhan. ${ }^{6}$ Di sinilah tugas konseling diperlukan sebagai tindakan pertolongan kepada indivdu yang ada dalam masalah baik dengan dirinya sendiri maupun dalam masyarakat. Kegiatan konseling pada umumnya dan konseling keluarga pada khsususnya dibutuhkan dalam mengatasi berbagai persoalan anak dalam rumah tangga.

Konseling (counseling) berasal dari counsel dari bahasa Latin yaitu counselium yang artinya "bersama" atau bicara bersama". Yang dimaksud bicara bersama adalah pembicaraan antara konselor dan konseli untuk membicarakan tentang pemecahan masalah yang dihadapi oleh konseli. Konselor adalah orang yang terlatih secara profesional untuk membantu individu mengalami kesulitan sedangkan konseli adalah individu yang memerlukan bantuan dalam memecahkan masalah. ${ }^{7}$ Konseling terjadi sejalan dengan persoalan-persoalan yang sementara terjadi di tengah masyarakat. Dimotivasi oleh fakta bahwa banyaknya tawuran antar geng dalam komunitas pemuda dan remaja, kekerasan secara simbolis melalui kata sembrono, berperilaku kasar, seks bebas dan perilaku-perilaku negatif lainnya mengakibatkan perlu adanya konseling dalam keluarga. ${ }^{8}$ Konseling keluarga adalah upaya bantuan yang diberikan kepada individu anggota keluarga melalui sistem keluarga (pembenahan komunikasi keluarga) agar potensinya

\footnotetext{
${ }^{2}$ Robert P.Masland, It's All About S Sex, 1

${ }^{3}$ J L. Ch, Abineno, Seksualitas dan Pendidikan Seksuil (Jakarta: BPK Gunung Mulia, 1983)., 42.

${ }^{4}$ Robert P.Masland, It's All About S Sex, 116,117

${ }^{5}$ Jacob Daan Engel, Konseling Masalah Masyarakat, (Yogyakarta:PT Kanisius, 2018), 1-2.

${ }^{6}$ Jacob Daan Engel, Konseling Pastoral dan Isu-Isu Kontemporer, (Jakarta:BPK Gunung Mulia,2016),

${ }^{7}$ Giyono, Konseling Lintas Budaya,(Yogyakarta:media akademi,2016), 3

${ }^{8}$ Jacob Daan Engel, Konseling Pastoral dan Isu-Isu Kontemporer, 53
} 
berkembang seoptimal mungkin dan masalahnya dapat diatasi atas dasar kemauan membantu dari semua anggota keluarga berdasarkan kerelaan dan kecintaan terhadap keluarga. Menurut Golden dan Sherwood, konseling keluarga adalah metode yang dirancang dan difokuskan pada keluarga dalam usaha untuk membantu memecahkan masalah perilaku klien.Sehingga konseling keluarga merupakan proses bantuan yang diberikan kepada individu anggota keluarga dalam memecahkan masalah kelurga yang dihadapinya. ${ }^{9}$ Konseling keluarga memandang keluarga secara keseluruhan bahwa anggota keluarga adalah bagian yang tidak mungkin dipisahkan dari anak (klien) baik dalam melihat permasalahannya maupun penyelesaiannya. Sebagai suatu sistem, permasalahan yang dialami seorang anggota keluarga akan efektif diatasi jika melibatkan anggota keluarga yang lain. Pada mulanya konseling keluarga terutama diarahkan untuk membantu anak agar dapat beradaptasi lebih baik untuk mempelajari lingkungannya melalui perbaikan lingkungan keluarganya. Yang menjadi klien adalah orang yang memiliki masalah pertumbuhan di dalam keluarga baik orang tua maupun anak. Sedangkan masalah yang dihadapi adalah menetapkan apa kebutuhan dia dan apa yang akan dikerjakan agar tetap bertahan di dalam sistem keluarganya. ${ }^{10}$ Konseling keluarga secara teoritis berorientasi pada perilaku manusia. Tujuannya adalah untuk mengeksplorasi dinamika internasional, menggerakan kekuatan internal dan sumber daya fungsional dalam keluarga serta merekonsturksi interaksional maladaptif dan merancangkan pemecahan masalah perilaku dalam keluarga. Konseling keluarga bertujuan pada bagaimana komponen dari sebuah sistem berinteraksi, bagaimana keseimbangan dapat dicapai, bagaimana pola komunikasi yang fungsional berkembang dalam keluarga. ${ }^{11}$

Dalam model konseling keluarga, Minuchin membuat penyusunan ulang atas kesatuan keluarga sehingga keluarga berfungsi secara lebih efektif dan potensi pertumbuhan setiap anggotanya akan lebih maksimal. Empat model konseling keluarga tersebut yaitu model strategi pemecahan masalah, model interaksional konseling, model solusi terokus dan model terapi narasi. Penelitian ini menggunakan model Terapi Narasi dalam konseling keluarga. Model narasi menekankan pemberdayaan konseli dengan membantu mereka dalam "eksternalisasi" masalah mereka. Konseli datang ke konselor terlibat dengan "internalisasi wacana" atau penghayatan secara mendalam tentang masalah yang dihadapi oleh klien untuk memikirkan dan mendiskusikan masalah tersebut dalam hal kepribadian dirinya atau orang lain. ${ }^{12}$

Persoalan dalam keluarga yang menjadi fokus dalam penelitin ini yaitu anak dengan kecanduan masturbasi. Berdasarkan hasil konseling dengan klien, kecanduan masturbasi yang dialaminya diakibatkan karena disfungsi keluarga. Kesibukan orang tua dalam aktifitas dan pekerjaan sehari-hari mengakibatkan kurangnya waktu luang (quality time) bersama keluarga (anak) sehingga orang tua gagal melaksanakan fungsi-fungsinya. Salah satu fungsi yang gagal yaitu memberikan pendidikan seks kepada anak sehingga polusi media membuat anak jatuh ke dalam persoalan-persoalan seksualitas salah satunya kecanduan masturbasi. Selain itu, anak cenderung menutup diri dari perubahan perilaku, dan perubahan fisik yang berkaitan dengan reproduksi dan seksual. Kecenderungan anak menghindari quality time bersama orang tua juga bisa jadi karena ketidaknyamanan akibat sikap otoriter orang tua yang selalu memarahi dan menhukum anak. Membuat anak tidak dapat secara bebas dan terbuka menceritakan perasaannya pada orang tua. Sikap ini kemudian membawanya kepada pergaulan bersama teman-teman di luar yang lebih bisa memberikan kebebasan untuk berekspresi. Dengan demikian, orang tua harus mampu peka terhadap perubahan pada anak yang berkaitan dengan fisik dan psikologis anak sehingga orang tua dapat membangun komunikasi dengan terkait permasalahan tertentu yang dihadapi anak. Dibutuhkan kemampuan orang tua untuk mengkomunikasikan kepada anak dengan metode atau pendekatan yang tepat sehingga anak dapat dituntun untuk tidak jatuh dalam berbagai macam persoalan, lebih khusus peroalan yang berkaitan dengan seksualitas.

${ }^{9}$ Sestuningsih Margi Rahayu, Konseling Keluarga Dengan Pendekatan Behavioral:Strategi Mewujudkan Keharmonisan, Roceeding Seminar Dan Lokakarya Nasional Revitalisasi Laboratorium Dan Jurnal Ilmiah Dalam Implementasi Kurikulum Bimbingan Dan Konseling Berbasis KknI, 4 -6 Agustus 2017, Malang, Jawa Timur, Indonesia, 267 Dalam http://journal2.um.ac.id/index.php/sembk/article/view/1295/667 ${ }^{10}$ Sumarwiyah Edris Zamroni Richma Hidayati, Solution Focused Brief Counseling (Sfbc): Alternatif Pendekatan Dalam Konseling Keluarga, Jurnal Konseling GUSJIGANG Vol. 1 No. 2 Tahun 2015 ISSN 2460-1187, dalam https://core.ac.uk/download/pdf/304202205.pdf

${ }^{11}$ Jacob Daan Engel, Konseling Pastoral dan Isu-Isu Kontemporer, 56

${ }^{12}$ Jacob Daan Engel, Konseling Pastoral dan Isu-Isu Kontemporer,58,60. 


\section{Metode}

Metode yang digunakan dalam penelitian ini adalah penelitian kualitatif. Teknik pengumpulan data adalah dengan melakukan wawancara mendalam untuk mengumpulkan berbagai informasi penting dari responden. Dalam penelitian ini, responden (klien) memberikan tanggapannya dengan caranya sendiri. Karena itu konselor membiarkan responden menetapkan laju wawancara dan memilih arahnya. Peneliti memberikan rancangan yang minimal, sekadar cukup untuk membuat responden mulai bicara dan untuk mempertahankan menggali pembicaraannya.

Penelitian ini juga menggunakan model dan teknik konseling keluarga dengan sistematikanya yaitu model strategi pemecahan masalah dengan teknik intensitas dan refarming atau relabeling. Anonimitas dilakukan untuk melindungi subjek penelitian dengan menjaga privasi mereka karena penelitian ini sangat berkaitan dengan persoalan yang sensitif. Partisipasi dalam proyek penelitian juga harus sukarela di mana peneliti tidak memaksa secara psikologis atau fisik subjek untuk mengambil bagian dalam penelitian. ${ }^{13}$

\section{Hasil dan Pembahasan}

Peneliti (konselor) melalukan konseling dengan klien yang mempunyai masalah dengan kecanduan masturbasi. Klien bernama Rusdi (bukan nama sebenarnya). Klien berusia 16 tahun dan masih bersekolah di salah satu SMA di Kota Kalabahi. Klien tinggal di desa Motongbang, kecamatan Teluk Mutiara, kabupaten Alor, Nusa Tenggara Timur. Ayahnya seorang Guru dan ibunya seorang karyawan swasta. Klien adalah anak bungsu dari 5 bersuadara. Klien adalah seorang introvert yang lebih suka menghabiskan waktunya di kamar sendirian. Dari hari senin sampai sabtu, ayahnya sibuk mengajar di salah satu sekolah Negeri di Kota Kalabahi sedangkan ibunya sibuk bekerja di kantor sampai sore hari. Kakak-kakaknya pun demikian. Karena jarak usia yang jauh membuat mereka tidak begitu akrab. Ke lima kakaknya sudah menikah sehingga mereka sudah memiliki kehidupannya masing-masing.

Masalah yang dihadapi oleh klien sehingga klien merasa membutuhkan layanan konseling yaitu kecanduan masturbasi. Menurut penuturan klien, pertama kali ia melakukan masturbasi adalah saat klien mulai memasuki pubertas yaitu di kelas 1 SMP. Namun sejak SD klien sudah mengenal tentang seks dan fungsi penis yang tidak sekadar sebagai alat ekskresi air kencing. Klien pertama kali melakukan masturbasi dengan melihat video porno. Saat menontonnya, klien merasakan ada hal yang berubah dari reaksi alat kelaminnya. ${ }^{14}$ Maslan (2003) menyatakan bahwa masturbasi adalah bagian yang normal dalam penemuan diri. Meskipun tidak esensial terhadap proses fisik dari perkembangan seksual manusia, masturbasi merupakan kegiatan yang umum dilakukan baik laki-laki ataupun perempuan. Masturbasi mungkin memiliki nilai psikologis yang positif sebagai cara untuk membebaskan ketegangan seksual dan melepaskan energi seksual. Tidak ada efek samping secara jasmaniah akibat melakukan masturbasi. ${ }^{15}$

Klien juga menceritakan bahwa, sebelum klien melakukan masturbasi, klien sudah mengalami mimpi basah. Sejak itu penisnya selalu ereksi meskipun dengan melihat gambar porno. Dan setiap kali klien tidur, klien serasa ingin memegang dan mengelus penis yang ereksi tersebut, dan merasakan sedikit sensasi. Namun, klien belum mengetahui tentang ejakulasi atau penis akan mengeluarkan air mani dan sperma jika dilakukan terus menerus. ${ }^{16}$ Saat klien mengalami mimpi basah maupun masturbasi, tanpa sadar klien sementara melakukan aktifitas seksual. Aktifitas seksual adalah tindakan fisik atau mental yang menstimulasi, merangsang dan memuaskan secara jasmaniah. Tindakan itu dilakukan sebagai cara penting bagi seseorang untuk mengekspresikan perasaan dan daya tarik kepada orang lain. Mereka yang terlibat dalam aktifitas seksual apakah sendiri atau dengan orang lain, sungguh-sungguh karena menyenangkan. ${ }^{17}$ Dan inilah yang sebenarnya sementara dilakukan oleh Klien.

Selain karena dorongan seksual, mastrubasi yang dilakukan oleh klien juga disebabkan pengaruh teman sebaya. Hal ini terlihat dari penuturan klien bahwa;

"keinginan saya untuk melakukan masturbasi lagi, karena saya bersama teman-teman sekolah diajak untuk menonton video porno.Ketika tidur pikiran dan ingatan saya terbayang pada video porno tersebut membuat saya ingin terus melakukan masturbasi di kamar sendirian dengan sensasi membayangkan video porno yang ditonton sebelumnya, pada saat masturbasi dan ejakulasi pertama saya, jantung saya berdebar, dan pelir saya sakit, secara perasaan saya langsung takut dan

\footnotetext{
${ }^{13}$ Amir B. Marvasti, Qulitative Research In Sociology,(London:Sage Publication, 2004),135-137.

${ }^{14}$ Hasil Wawancara dengan Rusdi pada 13 Maret 2021.

${ }^{15}$ Robert P.Masland, It's All About S Sex, 116,117

${ }^{16}$ Hasil Wawancara dengan Rusdi pada 13 Maret 2021

${ }^{17}$ Robert P.Masland, It's All About S Sex, 43-44
} 
merasa bersalah takut terjadi apa-apa dengan diri saya secara fisik. Dan sejak saat itu, saya selalu merasakan perasaan-perasaan seksual seperti itu. ${ }^{18}$

Berdasarkan pemaparan klien terlihat bahwa pengaruh teman sebaya sangat besar dalam membentuk pengalaman seksual klien.

Klien kemudian melanjutkan untuk menyampaikan inti dari permasalahan yang dihadapinya. Klien menceritakan bahwa;

"Selama melakukan masturbasi memang ada kenikmatan tersendiri yang dirasa, yang kadang membuat saya sulit untuk berusaha berhenti melakukannya. Selama melakukan masturbasi memang ada sensasi kenikmatan pada tubuh, dan ejakulasi membuat tubuh terasa bergetar dan jantung berdebar kencang. Namun setiap kali selesai melakukan itu, setelah ejakulasi langsung timbul perasaan takut secara fisik jika terjadi apa-apa, perasaan malu pada diri sendiri dan perasaan bersalah yang membuat saya terus pikiran tentang itu. Dan biasanya hari di mana saya melakukan masturbasi pasti saya tidak akan berdoa karena merasa malu dan berdosa kepada Tuhan. Saya juga takut jika terjadi apa-apa pada penis saya." 19

Secara jasmaniah, tidak ada efek samping akibat melakukan masturbasi. Kalaupun ada istilah "efek samping", ini mengindikasikan moralitas, sikap yang mengupas secara kritis bahwa masturbasi merupakan ketidaknormalan. Bukan masalah yang luar biasa selama masa remaja, bagi laki-laki maupun perempuan, jika mereka merasa bersalah atau malu melakukan masturbasi. Rasa bersalah ini biasanya berasal dari para remaja yang mempercayai bahwa orang tua mereka atau orang dewasa lain akan mencela kegiatan itu atau karena stigma sosial dikaitkan terhadap masturbasi. ${ }^{20}$ Dengan demikian ketakutan yang dihadapi oleh klien dapat dikatakan sebagai hal yang wajar. Teori psikoanalitik membedakan rasa malu dan rasa bersalah. Mereka mengakui bahwa keduanya merupakan jenis dinamika moral yang berbeda. Hal ini muncul dari perbedaan motivasi yang muncul dari hati nurani positif dan negatif. Rasa bersalah mendorong seseorang untuk menyesuaikan diri pada standar moral, yakni dengan cara tunduk, patuh atau menolak Biasanya seorang mengalami rasa bersalah karena ia melakukan apa yang menurutnya tidak harus dilakukan. Salah satu bagian yang tak terpisahkan dari rasa bersalah yaitu perasaan rendah diri. Perasaan rendah diri adalah dampak dari kegagalan, bukan dari pelanggaran. Perasaan ini adalah ungkapan diri sendiri, bukan ungkapan rasa takut ditolak oleh orang yang berautoritas, bahkan "orang berautoritas" yang telah diinternalisasi. ${ }^{21}$ Sehingga perasaan rasa bersalah, malu bahkan rendah diri yang dialami oleh klien diakibatkan karena kegagalan dalam mengikuti otoritas moral yang ada di dalam lingkungannya.

Masturbasi adalah persoalan individual. Secara khusus, mustahil memberikan jawaban untuk menduga berapa kali seseorang dapat melakukan masturbasi. Namun apabila dalam melakukan aktivitas normal dan seseorang diganggu oleh pikiran tentang masturbasi, hal ini harus segera dikonsultasikan dengan psikiater keluarga atau seorang konselor. ${ }^{22}$ Akibat yang sama juga dialami oleh klien. Dampak karena klien terlalu sering melakukan masturbasi adalah konsentrasinya terganggu saat di sekolah sehingga prestasi akademiknya menurun. Hal ini juga mengakibatkan pandangan klien terhadap perempuan menjadi berbeda yaitu selalu mengarah ke hal-hal yang berkaitan dengan seksual. Selain itu ereksi penis menjadi tidak menentu ketika pikiran tiba-tiba membayangkan hal-hal porno. Dan yang paling fatal menurutnya adalah akhirnya ia melakukan hubungan seks dengan pasangannya di luar nikah.

Akibat-akibat tersebut membuat klien akhirnya memutuskan untuk melakukan kegiatan konseling. Menurut klien, ada rasa ingin berhenti namun berawal sejak kali pertama klien melakukan masturbasi, meskipun merasa bersalah namun ereksi penis tidak menentu tersebut seakan memaksa klien untuk terus melakukan masturbasi. Setelah melakukan masturbasi sering ada kenikmatan dan kesenangan tersendiri yang membuat klien tidur lebih nyenyak. Keinginan melakukan masturbasi pun sering dilakukan ketika klien sedang mengalami stres ataupun kesulitan tidur. Hal ini membuat klien kecanduan untuk melakukannyaa. Klien pernah berusaha untuk berhenti, dengan mencari informasi-informasi yang dapat membantunya. Klien mencoba mencari kesibukan lain, tidak sendirian di dalam kamar, namun ketika klien sendiri di rumah maka hasrat untuk melakukan masturbasi kembali muncul. Selain itu pergaulan bersama teman-teman yang juga memiliki pengalaman yang sama kemudian saling membenarkan perilaku masturbasi dan perilaku seksual mereka yang lain.

\footnotetext{
${ }^{18}$ Hasil Wawancara dengan Rusdi pada 13 Maret 2021

${ }^{19}$ Hasil Wawancara dengan Rusdi pada 13 Maret 2021

${ }^{20}$ Robert P.Masland, It's All About S Sex ,116,117

21 John C. Hoffman, Permasalahan Etis Dalam Konseling, (Yogyakarta:Kanisius, 1993), 105-107

${ }^{22}$ Robert P.Masland, It's All About S Sex, 118
} 
Klien memiliki kedekatan dengan ibunya karena itu besar harapan klien untuk menceritakan masalah yang dialami kepada ibunya. Keinginan itu semakin besar ketika salah seorang saudara perempuan klien mengalami persoalan yaitu hamil di luar nikah. Klien mengalami kecemasan kalau klien akan jatuh ke dalam hal yang sama apabila rasa kecanduannya tidak dapat diatasi. Namun klien merasa malu dan takut. Klien menyadari bahwa klien jatuh ke dalam persoalan ini karena saat memasuki masa pubertas, klien memperoleh pengetahuan tentang seks dan masturbasi hanya melaui beberapa informasi di internet. Di Sekolah klien tidak mendapat bimbingan mendalam berkaitan dengan masturbasi. Dengan demikian, orang tua perlu menyadari bahwa keluarga merupakan tempat pertama anak mendapatkan berbagai macam pengetahuan tentang kehidupan. Pendidikan adalah pertama-tama tugas orang tua. Tujuan pendidikan ialah membantu anak-anak, supaya mereka dengan baik dan secara bertanggung jawab dapat mengembangkan kemungkinan-kemungkinan yang ada pada mereka. Dalam tugas mendidik, satu hal yang tidak dapat dilupakan oleh orang tua yaitu Sex education.

Sex education atau pendidikan seks merupakan instruksi dalam fisiologi perkembangbiakan dan pada sikap-sikap yang dapat meningkatkan penyesuaian diri seksual yang baik terhadap seksualitas pada umumnya dan dalam perkawinan khsusunya. ${ }^{23}$ Para guru dan orang tua seringkali merasa tidak enak dengan pendidikan seks, karena mereka yakin bahwa anak-anak muda akan aktif secara seksual setelah memperoleh informasi tentang seks. ${ }^{24}$ Akibatnya seks dan seksualitas dianggap sebagai sesuatu yang tabu dan seringkali di tutup-tutupi. ${ }^{25}$ Dalam penerangan tentang seksualitas yang terpenting bagi anak-anak bukanlah pertama-tama pengetahuan tentang fakta-fakta biologis. Fakta-fakta tersebut tidak ada guna kalau mereka tidak dibimbing untuk melihatnya dalam hubungannya yang sebenarnya. Fakta-fakta biologis yang hakiki tentang manusia : tentang masa lampaunya, tentang panggilannya, tentang tanggung jawabnya, tentang masa depannya. ${ }^{26}$ Proses pendampingan ini yang sering diabaikan oleh orang tua. Istilah pendampingan sendiri berasal dari kata kerja mendampingi yang berarti suatu kegiatan kemitraan, karena suatu sebab perlu didampingi. ${ }^{27}$ Orang tua adalah mitra yang seharusnya mendampingi anak untuk memahami berbagai fenomena yang terjadi di sekitar anak. Tugas orang tua adalah mendidik dan membimbing anak-anak itu dengan baik, sehingga seksualitas mereka dapat berkembang dengan sehat. ${ }^{28}$

Dalam suatu proses konseling, pendidikan rendah, baik formal maupun nonformal sering menjadi akar permasalahan klien yang mengalami low spiritual self-esteem, menggambarkan ketidakmampuan kesadaran diri klien mengidentifikasi kekuatan dan kelemahan dirinya, dan karena itu diperlukan pemberdayaan yang mengarah pada perubahan sikap dan perilaku sehat. ${ }^{29}$ Pendidikan dapat menjadi penting dalam menumbuhkembangkan healthy spiritual self-esteem agar orang-orang memiliki pandangan yang seimbang dan akurat terhadap dirinya, mempunyai nilai diri atu spiritual, menghormati kemampuan diri, tetapi mengakui kelemahannya serta rasa hormat dari dan terhadap orang lain. ${ }^{30}$ Berkaitan dengan masturbasi, pendidikan seksualitas yang rendah sangat berpengaruh terhadap aktifitas seksual anak sehingga tanpa disadari anak mengalami low spiritual self-esteem. Perasaan bersalah, ketakutan, perasaan berdosa.

Pendidikan seks dimulai sejak lahir. Sarwono mengukapkan bahwa orangtua cenderung mengabaikan pertanyaan anak-anaknya tentang segala sesuatu yang berkaitan dengan seks. Reaksi orang tua tersebut seperti pura-pura tidak mendengar atau mengalihkan pembicaraan. Bahkan tidak jarang anak dimarahi karena mengajukan pertanyaan seputar seksualitas. Hal ini dikarenakan sebagian besar orang tua memahami seks hanya sebatas hubungan seks. ${ }^{31}$ Namun keluarga, perlu memberikan perhatian secara khusus bagi anak berkaitan dengan pengetahuan tentang seksualitas terutama di masa remaja atau saat di mana anak akan memasuki masa pubertas. Dalam ilmu jiwa, seksualitas acapkali timbul sebagai unsur yang sangat penting. Dengan demikian individu tidak dapat hidup secara efektif kalau tidak mampu

${ }^{23}$ J.P. Chaplin Penerjemah. Dr. Katini Kartono, Kamus Lengkap Psikologi, (Jakarta:PT

Rajagrafindo Persada, 2005),459

${ }^{24}$ Robert P.Masland, It's All About S Sex, 21

25 J, L. Ch, Abineno, Seksualitas dan Pendidikan Seksuil,46,59

${ }^{26}$ J, L. Ch, Abineno, Seksualitas dan Pendidikan Seksuil,,37-38.

${ }^{27}$ Jacob Daan Engel, Pendampingan Keindonesiaan, (Jakarta : BPK Gunung Mulia,2020), 1

${ }^{28}$ J, L. Ch, Abineno, Seksualitas dan Pendidikan Seksuil ,14.

${ }^{29}$ Jacob Daan Engel, Model Logo Konseling untuk Memperbaiki Low Spiritual Self-

Esteem,(Yogyakarta:Kanisius2014) ,2

${ }^{30} \mathrm{Jacob}$ Daan Engel, Model Logo Konseling ,2

${ }^{31}$ Ed. Christina Siwi Handayani, Representasi Soial,4 
menghargai seksualitasnya sendiri dan memiliki harga diri sebagai makhluk seksual. Ini berarti individu sanggup untuk memandang dirinya sendiri sebagai seseorang yang patut dihargai oleh orang lain sebagai makhluk seksual terutama oleh orang-orang dari kelamin yang berbeda. ${ }^{32}$

Lawren Creemun mendefinisikan pendidikan sebagai usaha sengaja sistematis dan terus menerus untuk menyampaikan, menimbulkan atau memperoleh pengetahuan, sikap-sikap, nilai-nilai, keahlian, atau kepekaan-kepekaan juga setiap akibat dari usaha itu. Salah satu kekuatan definisinya tekanannya pada pendidikan sebagai kegiatan yang dilakukan secara "sengaja" sistematis dan terus menerus. Dalam pandangan ini pendidikan selalu mewajibkan kesengajaan. Dapat dinyatakan bahwa seluruh pengalaman adalah pendidikan. ${ }^{33}$ Dengan demikian, atas persetujuan yang sukarela dari keluarga klien maka konselor melakukan konseling keluarga untuk memberdayakan seluruh anggota keluarga, agar keluarga dapat eksis dalam pengertian masalah salah satu anggota keluarga menjadi masalah dalam suatu sistem.

\section{Model Konseling Keluarga}

Tujuan dari konseling adalah membantu konseli mengalami pengalamannya dan menerima kenyataan. Melalui proses konseling, klien dapat mengalami pengalamannya dan menerima apa yang terjadi dalam dirinya secara penuh dan utuh (acceptance). Tujuan kedua adalah membantu konseli mengungkapkan diri secara penuh dan utuh. Melalui konseling, klien dibantu agar dapat mengekspresikan perasaan, keinginan dan aspirasinya. Dan yang terakhir adalah membantu konseli bertumbuh dan berubah. Selain itu konseling juga dapat membantu konseli untuk menciptakan dan bertingkah laku yang baru yang lebih sehat. ${ }^{34}$

Model yang dipilih oleh konselor sesuai dengan masalah yang dihadapi oleh klien yaitu Model Terapi Narasi. Model narasi menekankan pemberdayaan konseli dengan membantu mereka dalam "eksternalisasi" masalah mereka. Konseli datang ke konselor terlibat dengan "internalisasi wacana" atau penghayatan secara mendalam tentang masalah yang dihadapi oleh klien untuk memikirkan dan mendiskusikan masalah tersebut dalam hal kepribadian dirinya atau orang lain. Dalam proses ini, konselor diharapkan dapat menggali dan memahami pengalaman konseli secara baik. Teknik yang dipakai adalah intensitas. Teknik intensitas menyoroti tema keluarga atau penekanan dengan harapan akhirnya memodifikasi interaksi keluarga.Misalnya: konselor memungkinkan konseli untuk memiliki fase untuk menyampaikan masalah yang ia hadapi yaitu kecanduan masturbasi dan kemudian mendorong orang tua untuk mengambil alih dan menanggapi situasi yang ada. Tanggapan dari orang tua adalah kaget, bingung, dan memarahi anak tersebut dengan pertimbangan bahwa itu masturbasi merupakan hal yang buruk dan tercela. Hal ini dimungkinkan sebab orang tua masih memiliki pemahaman bahwa seks dan persoalan seksualitas adalah sesuatu yang bersifat tabu dan tertutup. Tindakan-tindakan seksual di luar ikatan pernikahan adalah dosa besar sehingga merupakan sesuatu yang wajar apabila respon orang tua adalah memarahi klien.

Teknik yang berikutnya adalah teknik reframing atau relabeling digunakan oleh konselor keluarga struktural, strategi dan perilaku. Dalam reframing konselor mengubah informasi yang disajikan oleh keluarga untuk memberikan arti baru dan lebih bermanfaat. Konselor memberikan pemahaman bahwa pendidikan adalah tanggung jawab bersama dari kedua orang tua termasuk pendidikan atau pengetahuan tentang seksualitas. Keluarga merupakan tempat yang paling penting dalam melaksanakan pendidikan seksual karena pendidikan seksual merupakan pendidikan yang paling hakiki. Memang banyak orang tua berada dalam kesalahpahaman bahwa tugas orang tua adalah mendidik anak-anak mereka agar dapat hidup sopan dan suci karena itu pembicaraan soal-soal seksualitas cenderung dihindari. Namun anak memiliki rasa keingintahuan yang tinggi. Misalnya pertanyaan tentang dari mana datangnya seorang bayi maupun bagiamana bayi itu dibuat. Hal tersebut sangat berbahaya apabila anak mengetahui dari kawankawan mereka di sekolah maupun dari internet. Dengan demikian yang paling tepat untuk memberikan bimbingan kepada anak-anak dibidang seksualitas adalah orang tua. ${ }^{35}$

\footnotetext{
${ }^{32}$ Aart Martin Van Beek, Konseling Pastoral: Sebuah Buku Pegangan bagi Para Penolong di Indonesia (Semarang:Satya Wacana, 1987), 149

${ }^{33}$ Thomas H. Groome, "Christian Religious, Education : Pendidikan Agama Kristen", (Jakarta : BPK Gunung Mulia, 2010), 29

${ }^{34}$ Totok S. Wiryasaputra, Pengantar Konseling Pastoral,(Yogyakarta:Diandra Pustaka Indonesia,97105.

35 J, L. Ch, Abineno, Seksualitas dan Pendidikan Seksuil,49-50.
} 
Rasa kepercayaan antara orang tua dan anak harus dibangun. Orang tua perlu menyadari bahwa dalam melaksanakan tugas mereka dalam mendidik anak, mereka harus punya pengetahuan yang baik tentang seks dan seksualitas. Konselor juga memberikan beberapa referensi terkait pengetahuan-pengetahuan tentang seksualitas baik dari brosur maupun dari media digital. Merupakan tanggung jawab orang tua untuk menyampaikan pengetahuan tentang seks dan seksualitas serta dampak-dampaknya bagi kehidupan mereka. Orang tua juga perlu mengetahui kebutuhan anak serta memfasilitasi untuk mereka dapat mengembangkan potensi yang mereka miliki terlebih di masa mereka sedang mencari jati diri sehingga anak tidak dapat jatuh ke dalam masalah-masalah salah satunya terkait persoalan seksualitas.

Dari proses ini, perubahan sikap yang terlihat adalah orang tua mulai membangun kedekatan kembali dengan anak seperti meluangkan lebih banyak waktu di rumah untuk berdiskusi bersama. Meja makan dapat menjadi tempat mereka saling bertukar pendapat tentang berbagai persoalan yang dihadapi anak. Konseli menjelaskan bahwa, setelah kegiatan konseling, orang tua mulai membangun percakapan terkait kehidupan pribadi klien misalnya dengan menanyakan "siapa pacar kamu dan sesekali bolehlah kenalkan dia dengan kami". Orang tua juga mulai memberi perhatian untuk memfasilitasi anak agar dapat mengembangkan potensinya yaitu memberikan peralatan melukis kepada anak sehingga anak dapat memanfaatkan waktu luangnya untuk melakukan hobi sekaligus mengembangkan potensinya.

\section{Simpulan}

Bimbingan dan konseling mempunyai peranan dan pengaruh yang signifikan dalam ranah nonformal, dalam rangka melakukan pencegahan, pengembangan, dan perbaikan terhadap kehidupan dan akar persoalan pribadi dan sosial anak dalam keluarga. Konseling keluarga secara teoritis berorientasi pada perilaku manusia. Tujuannya adalah untuk mengeksplorasi dinamika internasional, menggerakan kekuatan internal dan sumber daya fungsional dalam keluarga serta merekonsturksi interaksional maladaptif dan merancangkan pemecahan masalah perilaku dalam keluarga. Konseling keluarga bertujuan pada bagaimana komponen dari sebuah sistem berinteraksi, bagaimana keseimbangan dapat dicapai, bagaimana pola komunikasi yang fungsional berkembang dalam keluarga.

Orang tua sebagai partner bagi anak bertanggungjawab untuk mendampingi anak dalam proses perkembangannya. Dalam proses pendampingan, orang tua harus menginternalisasi nilai-nilai positif tentang seksualitas kepada anak melalui sex education. Terutama ketika anak ada dalam masa pubertas , orang tua sudah harus memberi pengetahuan tentang seksualitas secara terbuka. Seks bukan lagi hal tabu, tertutup dan samar-samar. Keluarga atau orang tua perlu memahami perkembangan seksualitas anak agar dapat mengarahkan secara baik. Dalam konseling keluarga, teknik refarming atau relabeling memberi informasi yang baru kepada orang tua, informasi yang mampu menjawab kebutuhan dari anggota keluarga. Dengan demikian konseling keluarga dapat memberdayakan semua anggota keluarga agar keluarga eksis dalam pengertian, masalah salah satu anggota keluarga menjadi masalah keluarga sebagai suatu sistem.

\section{Ucapan Terimakasih}

Pertama-tama penulis memanjatkan rasa syukur dan terima kasih kepada Tuhan yang Maha Esa atas penyertaanNya sehingga penulis dapat menyelesaikan penulisan karya ilmiah ini dengan baik. Penulis juga mengucapkan terima kasih kepada keluarga besar atas dukungan baik moril maupun materil. Ucapan terima kasih yang sama juga diberikan kepada klien dan keluarga besarnya untuk kerja sama selama proses penulisan karya ilmiah ini.

\section{Refrensi}

Abineno Ch. J.L, Percakapan Patoral dalam Praktik, Jakarta:BPK Gunung Mulia,2002.

Abineno Ch. J.1, Seksualitas dan Pendidikan Seksuil, Jakarta: BPK Gunung Mulia, 1983.

Beek Vaan, Aart Martin, Konseling Pastoral: Sebuah Buku Pegangan bagi Para Penolong di Indonesia, Semarang:Satya Wacana, 1987.

Chaplin ,J.P. Penerjemah. Dr. Katini Kartono, Kamus Lengkap Psikologi, Jakarta:PT Rajagrafindo Persada, 2005.

Engel, Daan Jacob, Konseling Masalah Masyarakat, Yogyakarta:PT Kanisius, 2018.

Engel, Daan Jacob, Konseling Pastoral dan Isu-Isu Kontemporer, Jakarta:BPK Gunung Mulia,2016.

Engel Daan Jacob, Model Logo Konseling untukMemperbaiki Low Spiritual SelfEsteem, Yogyakarta:Kanisius2014.

Engel, Daan Jacob, Pastoral dan Kebutuhan Dasar Konesling, Jakarta:BPK Gunung Mulia, 
2016

Engel Daan Jacob, Pendampingan Keindonesiaan, Jakarta : BPK Gunung Mulia,2020.

Giyono, Konseling Lintas Budaya,Yogyakarta:media akademi,2016.

Groome , H. Thomas, Christian Religious, Education : Pendidikan Agama Kristen, Jakarta : BPK Gunung Mulia, 2010.

Hoffman C. John, Permasalahan Etis Dalam Konseling, Yogyakarta:Kanisius, 1993.

J. Watt , J. Nisbet Studi Kasus :Sebuah Panduan Praktis, Jakarta : Gramedia Widiasarana Indonesia, 1994,16

Kalean H, Metode Penelitian Interdisipliner Bidang Sosial, Budaya, Filsafat, Seni, Agama dan Humaniora, Yogyakarta: Paradigma, 2012.

Masland, P. Robert, It's All About S Sex : A-Z tentang Sex, Jakarta:Bumi Aksara,2013.

Marvasti B. Amir, Qulitative Research In Sociology,London:Sage Publication, 2004.

Rahayu Margi Sestuningsih, Konseling Keluarga Dengan Pendekatan Behavioral:Strategi Mewujudkan Keharmonisan, Roceeding Seminar Dan Lokakarya Nasional

Revitalisasi Laboratorium Dan Jurnal Ilmiah Dalam Implementasi Kurikulum Bimbingan Dan Konseling Berbasis KknI, 4 -6 Agustus 2017, Malang, Jawa Timur, Indonesia.(online)Tersedia di http://journal2.um.ac.id/index.php/sembk/article/view/1295/667

Siwi Handayani, Ed. Christina, ,Representasi Soial:Seksualitas Kesehatan dan Identitas Kumpulan Penelitan Psiokologi, Yogyakarta:Universitas Sanata Dharma,2010.

Wiryasaputra S. Totok , Pengantar Konseling Pastoral,Yogyakarta:Diandra Pustaka Indonesia.

Zamroni Edris Sumarwiyah Richma Hidayati, Solution Focused Brief Counseling (Sfbc): Alternatif Pendekatan Dalam Konseling Keluarga, Jurnal Konseling GUSJIGANG Vol. 1 No. 2 $\begin{array}{lllll}\text { Tahun } & 2015 & \text { ISSN } & \text { 2460-1187 } & \text { (Online). }\end{array}$ https://core.ac.uk/download/pdf/304202205.pdf

Article Information (Supplementary)

Conflict of Interest Disclosu res:

The authors declare that they have no significant competing financial, professional or personal interests that might have influenced the performance or presentation of the work described in this manuscript.

Copyrights Holder: Selvy Putri Fabiola,2021

First Publication Right: JIBK Undiksha

https://doi.org/10.23887/jibk.v12i2.33143

O pen Access Article | CC-BY Creative Commons Attribution 4.0 International License.

Word Count: 